\title{
Antibacterial Activity of the Epidermal Mucus of Barbodes everetti
}

\author{
JIAZHEN LIM, YANG LEE, BADIOZAMAN SULAIMAN, LESLEY MAURICE BILUNG \& YEE \\ LING CHONG*
}

\author{
Faculty of Resource Science and Technology, Universiti Malaysia Sarawak, 94300 Kota Samarahan, Sarawak, \\ Malaysia \\ *Corresponding author: ylchong@unimas.my; yeelingchong@gmail.com
}

\begin{abstract}
The epidermal mucus of fish contains antimicrobial agents that act as biological defence against disease. This study aims to identify antibacterial activity and protein concentration of epidermal mucus of Barbodes everetti, a Bornean endemic freshwater fish. The epidermal mucus was extracted with $3 \%$ acetic acid, $0.85 \%$ sodium chloride and crude solvents. The mucus activity against eight strains of human pathogenic bacteria, including Bacillus cereus ATCC 33019, Escherichia coli O157:H7, Listeria monocytogenes ATCC 7644, Pseudomonas aeruginosa ATCC 27853, Salmonella braenderup ATCC BAA 664, Salmonella typhimurium, Staphylococcus aureus ATCC 25933, and Vibrio cholerae, were tested. The acetic acid mucus extract of B. everetti was able to inhibit five strains of bacteria and show no activity toward E. coli O157:H7, B. cereus ATCC 33019 and L. monocytogenes ATCC 7644. Moreover, the highest protein concentration was quantified in crude extract, followed by aqueous and acetic acid extracts. This study provides a preliminary knowledge on the activity of epidermal mucus of $B$. everetti towards five out of the eight human pathogens tested, therefore it may contain potential sources of novel antibacterial components which could be further extracted for the production of natural antibiotics towards humanrelated pathogenic bacteria.
\end{abstract}

Keywords: Antibacterial, antimicrobial properties, Barbodes everetti, epidermal mucus, pathogenic bacteria

Copyright: This is an open access article distributed under the terms of the CC-BY-NC-SA (Creative Commons Attribution-NonCommercialShareAlike 4.0 International License) which permits unrestricted use, distribution, and reproduction in any medium, for non-commercial purposes, provided the original work of the author(s) is properly cited

\section{INTRODUCTION}

Fish is the largest group of vertebrates on earth with approximately 33,900 species from 5,122 genera occupying and utilizing all the aquatic ecosystems (Kottelat, Whitten, Kartikasari \& Wirjoatmodjo, 1993). The commonly known clown barb or Everett's barb (Barbodes everetti) is a cyprinid found in Sumatra and Borneo (Kottelat et al., 1993) but it is claimed endemic to Borneo due to the absence of definitive record and evidence of existence in Sumatra. B. everetti can be found in clear and flowing or swiftly-moving forest streams with preference on quieter streams with depth no more than $15 \mathrm{~cm}$ (Kottelat et al., 1993).

The epidermal mucus of fish is a mucosal layer on the fish skin, which acts as the first line defence against any foreign environmental agents such as bacteria, fungus, parasites, chemicals, drugs or animal actions, including predations, competitions and abrasion injuries (Esteban, 2012; Zaccone, Meseguer, García-Ayala \& Kapoor, 2009). Foreign materials which approach and try to invade the fish will be entrapped in the mucosal layer and removed by the surrounding water current (Esteban, 2012). This layer of mucus is secreted by the epidermal and epithelial cells of fish to serve not only as protection but as lubricant that aid in locomotion and osmoregulation, as well as intra-specific chemical communication (Bernstein, Schluter \& Marcholonis, 1997; Kuppulakshmi, Prakash, Gunasekaran, Manimegalai \& Sarojini, 2008).

The antimicrobial properties of the epidermal mucus of fish may be related to their innate immune components such as the enzymes (e.g. lysozyme, acid and alkaline phosphate, cathepsins, etc.), proteases (i.e. serine, cysteine, aspartic and metallo-proteases), antibacterial peptides (e.g. alpha-helical amphipathic peptides, pardaxin, pleurocidins, etc.), lectins (e.g. congerin, AJL-1, etc.), proteins (e.g. lactoferrin, histone, ribosomal protein, etc.), or immunoglobins, and produce an undefined natural immunity in fish (Dhanaraj et al., 2009; Esteban, 2012; Fast, Sims, Burka, Mustafa \& Ross, 2002; Nigam, Kumari, Mittal \& Mittal, 2012; Palaksha, Shin, Kim \& Jung, 2008; Subramanian, MacKinnon \& Ross, 2007). The epidermal mucus of fish contains certain antimicrobial agents that protect the fish against the colonization of pathogenic microorganisms (Subramanian, Ross \& MacKinnon, 2008).

The study of Momoh, Mora, Ogbonna and Agboke (2014) revealed that the antimicrobial agents from the epidermal mucus of catfish can be used to substitute the present antibiotic in managing the clinical infectious diseases due to its higher permeability than commercial drug sample. However, there is limited published data of 
the antibacterial properties of epidermal mucus of Bornean freshwater fishes. Thus, the potential antibacterial agents of $B$. everetti is yet to be explored. Therefore, this study was undertaken to identify the antibacterial activity and protein contents of the epidermal mucus of $B$. everetti against different human pathogens.

\section{MATERIALS \& METHODS \\ Fish Collection and Maintenance}

Barbodes everetti were sampled from streams located at Kubah National Park $\left(1.6128{ }^{\circ} \mathrm{N}, 110.1969^{\circ} \mathrm{E}\right)$ and Paon Gahat Village $\left(0.9420^{\circ} \mathrm{N}, 110.6564{ }^{\circ} \mathrm{E}\right)$ by using $5 \mathrm{~L}$ minnow traps, from September 2017 to January 2018. The fishes were then maintained in aquariums at Molecular Ecology Laboratory, Faculty of Resource Science and Technology, Universiti Malaysia Sarawak. The fishes were acclimatized to laboratory conditions in carbon filtered water for one week prior to mucus collection.

\section{Mucus Collection and Storage}

Mucus was collected according to Ramesh (2013) with slight modification. The fishes were stressed by starving for a day prior to mucus collection in order to maximize the mucus secretion as well as to avoid defecation during the mucus collection process. During the mucus collection process, the fishes were first dipped into distilled water to remove any apparent dirt (Hisar et al., 2014) and transferred into an enclosed sterile polyethylene bag (zip lock bag) with approximately equal volume of distilled water at room temperature. The fishes were delicately massaged for a minute from outside of the polyethylene bag and moved back and forth to slough off the fish mucus. The fishes were then transferred to the recovery tanks. Collected mucus was lyophilized by using Labconco's Freezedryer (FreeZone ${ }^{\circledR}$ Plus ${ }^{\mathrm{TM}} 4.5$ Liter Cascade Freeze Dry Systems 7382033 ) and stored at $-20{ }^{\circ} \mathrm{C}$.

\section{Mucus Extraction and Protein Quantification}

Three types of mucus extraction were conducted in this study which are crude, aqueous and acidic extractions. For

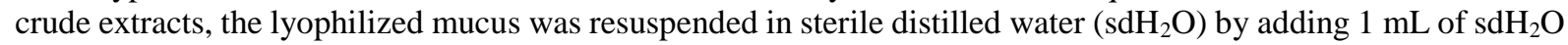
into every $1 \mathrm{mg}$ of lyophilized mucus. The resuspended mucus with the concentration of $1 \mathrm{mg} / \mathrm{mL}$ was centrifuged at $9,500 \times \mathrm{g}$ at $4{ }^{\circ} \mathrm{C}$ for 10 minutes. The aqueous mucus extracts were prepared by resuspending each $\mathrm{mg}$ of lyophilised mucus in $1 \mathrm{ml}$ of $0.85 \%$ sterile saline water $(0.85 \% \mathrm{NaCl})$ and centrifuged at $5,000 \mathrm{rpm}(1,369.55 \mathrm{~g})$ at room temperature for 15 minutes. While for the acidic extracts, the lyophilized mucus was resuspended in $3 \%$ acetic acid $\left(\mathrm{CH}_{3} \mathrm{COOH}\right)$ with the concentration of $1 \mathrm{~mL} / \mathrm{mg}$. It was then immersed into a boiling water bath for five minutes and immediately cooled in ice. Subsequently, the mixture was sonicated for 30 minutes by using a sonicator and centrifuged at $18,000 \times \mathrm{g}$ at $4{ }^{\circ} \mathrm{C}$ for 35 minutes. The supernatants of each extraction method were collected and filtered by using a syringe with sterile $0.22 \mu \mathrm{m}$ filter. The eluates were collected and stored at $4^{\circ} \mathrm{C}$.

\section{Bacteria Culture Conditions}

The antimicrobial activities of mucus extracts were tested against eight strains of human pathogenic bacteria including both Gram-positive (Bacillus cereus ATCC 33019, Listeria monocytogenes ATCC 7644, and Staphylococcus aureus ATCC 25933) and Gram-negative (Escherichia coli O157:H7, Pseudomonas aeruginosa ATCC 27853, Salmonella braenderup ATCC BAA 664, Salmonella typhimurium, and Vibrio cholerae) bacteria. All bacteria were grown in Luria-Bertani broth and maintained in Müller Hinton slant agar.

\section{Antibacterial Activity Screening and Protein Quantification}

The bacteria inhibition test was carried out based on Kirby-Bauer disc diffusion method while the paper discs with $6 \mathrm{~mm}$ diameter were prepared from Whatman paper No.1 (Ong, Xavier \& Marimuthu, 2010). A total of $20 \mu \mathrm{L}$ of each mucus extracts were impregnated onto the paper disc and further transferred into the Müller Hinton agar plates with $\mathrm{OD}_{600}=0.1$ bacteria culture. The plates were then incubated at $4{ }^{\circ} \mathrm{C}$ for an hour and further incubated at $37^{\circ} \mathrm{C}$ for another 16 to 18 hours. Similar procedure was tested on the negative controls by using $\mathrm{sdH}_{2} \mathrm{O}$ or different solvents $\left(0.85 \% \mathrm{NaCl}\right.$ and $\left.3 \% \quad \mathrm{CH}_{3} \mathrm{COOH}\right)$ separately and positive control by using Penicillin/Streptomycin. The bacterial inhibition test of each extract against each bacterium was done in triplicates. The average diameter of zones of inhibition surrounded each extract-contained disc were measured and recorded after 16 to 18 hours of incubation. The protein concentrations of each epidermal mucus extracts were quantified by using standard assay of Bradford method.

\section{Statistical Analysis}

Anderson-Darling normality test was used to determine the normality of data. One-way analysis of variance (ANOVA) was employed to analyse the data yielded for zone of inhibition while Tukey's post-hoc test was carried out to compare the significant differences between means at $\mathrm{p}$-value $<0.05$. 


\section{RESULTS \& DISCUSSION}

The results yielded from Kirby-Bauer bacteria inhibition test of the epidermal mucus extracts of $B$. everetti are presented in Table 1. The acetic acid extract of B. everetti's mucus was able to inhibit all tested bacteria at different strength, except for E. coli O157:H7, B. cereus ATCC 33019 and L. monocytogenes ATCC 7644. The aqueous extracts were only able to inhibit $P$. aeruginosa ATCC 27853 weakly and there was no positive inhibition result yielded from its crude extracts. The acetic acid extracts shown the strongest inhibition strength towards $P$. aeruginosa ATCC 27853 with the inhibition zone diameter of $11.08 \pm 0.18 \mathrm{~mm}$. Furthermore, the repeated experiment with negative controls (i.e. $\mathrm{sdH}_{2} \mathrm{O}, 0.85 \% \mathrm{NaCl}$ and $3 \% \mathrm{CH}_{3} \mathrm{COOH}$ ) shown that the solvents used to extract the epidermal mucus do not contain any antibacterial component.

Table 1. Mean diameter of zone of inhibition of Barbodes everetti mucus extracts towards eight different strains of bacteria.

\begin{tabular}{lcc}
\hline Bacteria & \multicolumn{2}{c}{ Mean diameter of zone of inhibition $(\mathrm{mm})^{1} \pm$ SE } \\
\cline { 2 - 3 } Gram negative bacteria & Acidic Extract & Aqueous Extract \\
Escherichia coli O157:H7 & & NI \\
Pseudomonas aeruginosa ATCC 27853 & $11.08 \pm 0.18$ & NI \\
Salmonella braenderup ATCC BAA 664 & $9.46 \pm 0.84$ & NI \\
Salmonella typhimurium & $8.65 \pm 0.38$ & NI \\
Vibrio cholerae & $10.13 \pm 0.27$ & NI \\
Gram positive bacteria & & NI \\
Bacillus cereus ATCC 33019 & NI & NI \\
Listeria monocytogenes ATCC 7644 & NI & NI \\
Staphylococcus aureus ATCC 25933 & $8.67 \pm 0.87$ & NI \\
\hline
\end{tabular}

${ }^{1}$ Bacterial inhibition test was done in triplicates for each type of mucus extract.

NI indicates there is no bacteria inhibition.

This study shows that E. coli O157:H7 and B. cereus ATCC 33019 were not inhibited by any of the epidermal mucus extracts of $B$. everetti. This is consistent with the previous studies where pathogenic strains of E. coli and B. cereus were not being inhibited by the epidermal mucus extracts of other species of fishes [i.e. Cynoglossus arel, Arius caelatus, Rita rita, Channa punctatus, Channa micropeltes, Channa striata, Oncorhynchus mykiss, Gadus morhua and Labrus bergylta] (Bragadeeswaran, Priyadharshini, Prabhu \& Rani, 2011; Hellio, Pons, Beaupoil, Bourgougnon \& Gal, 2002; Hisar et al., 2014; Kumari, Nigam, Mittal \& Mittal, 2011; Rao et al., 2015). Failure to inhibit bacterial growth of some pathogenic strains in this study could be due to the absence of specific antibacterial peptides in the fish epidermal extracts. Zaccone et al. (2009) stated that the compositions in fish epidermal mucus may serve as an alternative source of nutrient for the growth of bacteria. Furthermore, E. coli O157 is a virulent pathogen which is hard to be prevented once it was established, while B. cereus ATCC 33019 exhibits resistance towards various type of stresses and it has long-term survival capacity (Lee, Cheng \& Liu, 2017; Pennington, 2010). This study also shows that the epidermal mucus extracts of $B$. everetti failed to inhibit the growth of L. monocytogenes ATCC 7644, a bacterium that has never been tested in any fish species. The study of Masso-Silva and Diamond (2014) revealed that only a specific antibacterial peptide, namely piscidin, was able to inhibit the growth of bacteria L. monocytogenes among the others antibacterial peptides (i.e. $\beta$-defensin, hepcidins, cathelicidin and histone-derived peptides).

Three different extraction methods were employed in this study to screen the antibacterial activities of the epidermal mucus of $B$. everetti. The protein quantification results revealed that the highest amount of protein was found in its crude extracts (Table 2), and the one-way ANOVA and Tukey's post-hoc statistical test proven that there was a significant difference in the protein content between the acetic acid and crude extracts. According to Caprette (2015), the Coomassie Brilliant Blue (dye of Bradford's reagent) used in Bradford's assay may react fundamentally with arginine residues while react less vigorous with histidine, lysine, tyrosine, tryptophan, and phenylalanine residues. Therefore, the low protein concentration in acidic extracts might be explained by the reaction variations of the Coomassie Brilliant Blue in the Bradford's assay. Besides, the protein composition solubility of epidermal mucus in crude, aqueous and acidic solvent could possibly be caused by the different levels of protein contents in these extracts. Different solvents used in this study may extract different components in the epidermal mucus and result in different yields in the protein amounts. Previous study reported that the acidic solvent yielded acidic soluble components while aqueous soluble components were extracted in the aqueous solvents in the epidermal mucus of fish (Ong et al., 2010). 
Table 2. The protein concentration in three different epidermal mucus extracts of Barbodes everetti.

\begin{tabular}{lc}
\hline Extractions & Protein concentration $\pm \mathrm{SE}(\mu \mathrm{g} / \mu \mathrm{L})$ \\
\hline Crude Extracts & $0.1422 \pm 0.0178$ \\
Aqueous Extracts & $0.1484 \pm 0.0234$ \\
Acetic Acid Extracts & $0.0869 \pm 0.0236$ \\
\hline
\end{tabular}

The result also shown that the acetic acid extracts with the lowest protein concentration exhibited the strongest antibacterial strength among the three extracts. The study by Cole and Ganz (2000) stated that the peptides responsible for pathogen defence were readily soluble in the acidic solvents which selectively precipitated and denatured the proteins, thus leaving the cationic peptides in solution, which believed to be responsible for the antibacterial activity of fish epidermal mucus (Nigam, Kumari, Mittal \& Mittal, 2017). The key role in host defence in the epidermal mucus of fish against pathogenic bacteria infection is suggested to be the acidic soluble proteins, potentially paradaxin and pleurocidin from the fish mucus (Cole, Weis \& Diamond, 1997; Vennila et al., 2011).

\section{CONCLUSIONS}

In conclusion, the epidermal mucus of $B$. everetti exhibited the antibacterial properties towards five human pathogenic bacteria (i.e. Pseudomonas aeruginosa ATCC 27853, Salmonella braenderup ATCC BAA 664, Salmonella typhimurium, Staphylococcus aureus ATCC 25933, and Vibrio cholerae) and could be a potential source of novel antibacterial component in the production of organic antibiotics. Furthermore, the acetic acid extracts of fish epidermal mucus were more effective in bacterial inhibition than both aqueous and crude extracts of fish epidermal mucus, which might be due to the presence of acidic soluble peptides and low molecular weight cationic antibacterial peptides. Besides, the highest protein contents were found in the crude extracts, followed by the aqueous extracts, and lowest in acetic acid extracts. The differences could possibly be induced by the solubility of proteins in different solvents.

\section{ACKNOWLEDGEMENTS}

This project was funded by Tun Zaidi Chair with Grant No. F07/TZC/1592/2017. The authors thank Sarawak Forestry Corporation and Forest Department Sarawak for granting the permission and permit to conduct biological research (Permit No. NPW.907.4.4.(Jld.15)-15 and Park Permit No. WL8/2018). The authors would like to thank the Paon Gahat Village Head for the permission to conduct the fish sampling in the village. The authors would also like to thank Faculty of Resource Science and Technology, UNIMAS for the administrative supports.

\section{REFERENCES}

Bernstein, R. M., Schluter, S. F., \& Marcholonis, J. J. (1997). Immunity. In D. H. Evans (Eds.), The physiology of fishes (2 ${ }^{\text {nd }}$ ed.) (pp. 215-242). Boca Raton, Florida: CRC Press.

Bragadeeswaran, S., Priyadharshini, S., Prabhu, K., \& Rani, S. R. S. (2011). Antimicrobial and hemolytic activity of fish epidermal mucus Cynoglossus and Arius caelatus. Asian Pacific Journal of Tropical Medicine, 305309.

Caprette, D. R. (2015). Bradford protein assay. Retrieved April 26, 2018, from http://www.ruf.rice.edu/ bioslabs/methods/protein/bradford.htmL.

Cole, A. M., Weis, P., \& Diamond, G. (1997). Isolation and characterization of pleurocidin, an antimicrobial peptide in the skin secretions of winter flounder. The Journal of Biological Chemistry, 272(18), 12008-12012.

Cole, A. M., \& Ganz, T. (2000). Human antimicrobial peptides: Analysis and application. Biotechniques, 29(4), 822-831.

Dhanaraj, M., Haniffa, M. A., Singh, A. S. V., Ramakrishnan, M., Manikandaraja, D., \& Milton, J. M. (2009). Antibacterial activity of skin and intestinal mucus of five different freshwater fish species viz., Channa striatus, C. micropeltes, C. marulius, C. punctatus and C. gachua. Malaysian Journal of Science, 28(3), $257-$ 262.

Esteban, M. Á. (2012). An overview of the immunological defences in fish skin. International Scholarly Research Notices Immunology, 2012(853470), 1-29.

Fast, M. D., Sims, D. E., Burka, J. F., Mustafa, A., \& Ross, N. W. (2002). Skin morphology and humoral nonspecific defence parameter of mucus and plasma in rainbow trout, coho and Atlantic salmon. Comparative Biochemistry and Physiology, Part A, 132, 645-657.

Hellio. C., Pons, A. M., Beaupoil, C., Bourgougnon, N., \& Gal, Y. L. (2002). Antibacterial, antifungal and cytotoxic activities of extracts from fish epidermis and epidermal mucus. International Journal of Antimicrobial Agents, 20, 214-219.

Hisar, O., Hisar, S. A., Uyanik, M. H., Sahin, T., Cakir, F., \& Yilmaz, S. (2014). In vitro antimicrobial and antifungal activities of aqueous skin mucus from rainbow trout (Oncorhynchus mykiss) on human pathogens. Marine Science and Technology Bulletin, 3(1), 19-22. 
Kottelat, M., Whitten, A. J., Kartikasari, S. N., \& Wirjoatmodjo, S. (1993). Freshwater fishes of Western Indonesia and Sulawesi. Hong Kong: Periplus Editions.

Kumari, U., Nigam, A. K., Mittal, S., \& Mittal, A. K. (2011). Antibacterial properties of the skin mucus of the freshwater fishes, Rita rita and Channa punctatus. European Review for Medical and Pharmacological Science, 2011(15), 781-786.

Kuppulakshmi, C., Prakash, M., Gunasekaran, G., Manimegalai, G., \& Sarojini, S. (2008). Antibacterial properties of fish mucus from Channa punctatus and Cirrhinus mrigala. European Review for Medical and Pharmacological Sciences, 12, 149-153.

Lee, A., Cheng, K. C., \& Liu, J. R. (2017). Isolation and characterization of a Bacillus amyloliquefaciens stain with zearalenone removal ability and its probiotic potential. PloS one, 12(8), 1-21.

Masso-Silva, J. A., \& Diamond, G. (2014). Antimicrobial peptides from fish. Pharmaceuticals, 7, 265-210.

Momoh, M. A., Mora, A. T., Ogbonna, J. D. N., \& Agboke, A. A. (2014). In vitro evaluation of antimicrobial activity of cat fish slime mucin on selected micro-organism by agar diffusion method. Pakistan Journal of Zoology, 46(6), 1747-1751.

Nigam, A. K., Kumari, U., Mittal, S., \& Mittal, A. K. (2012). Comparative analysis of innate immune parameters of the skin mucous secretions from certain freshwater teleosts, inhabiting different ecological niches. Fish Physiology and Biochemistry 38, 1245-1256.

Nigam, A. K., Kumari, U., Mittal, S., \& Mittal, A. K. (2017). Evaluation of antibacterial activity and innate immune components in skin mucus of Indian major carp, Cirrhinus mrigala. Aquaculture Research, 48(2), 407-418.

Ong, Y. W., Xavier, R., \& Marimuthu, K. (2010). Screening of antibacterial activity of mucus extract of snakehead fish, Channa striatus (Bloch). European Review for Medical and Pharmacological Sciences, 14, 675-681.

Palaksha, K. J., Shin, G. W., Kim, Y. R., \& Jung, T. S. (2008). Evaluation of non-specific immune components from the skin mucus of olive flounder (Paralichthys olivaceus). Fish and Shellfish Immunology, 24, 479-488.

Pennington, H. (2010). Escherichia coli O157. Lancet, 376, 1428-1435.

Ramesh, B. (2013). Assessment of antimicrobial peptides from mucus of fish. International Journal of Current Biotechnology, 1(1), 5-8.

Rao, V., Marimuthu, K., Kupusamy, T., Rathinam, X., Arasu, M. V., Al-Dhabi, N. A., \& Arockiaraj, J. (2015). Defence properties in the epidermal mucus if different freshwater fish species. Aquaculture, Aquarium, Conservation \& Legislation International Journal of Bioflux Society, 8(2), 184-194.

Subramanian, S., MacKinnon, S., \& Ross, N. W. (2007). A comparative study on innate immune parameters in the epidermal mucus of various fish species. Comparative Biochemistry and Physiology, Part B, 148, 256263.

Subramanian, S., Ross, N. W., \& MacKinnon, S. L. (2008). Comparison of antimicrobial activity in the epidermal mucus extracts of fish. Camparative Biochemistry and Physiology, Part B, 150, 85-92.

Vennila, R., Kumar, K. R., Kanchana, S., Arumugam, M., Vijayalakshmi, S., \& Balasubramaniam, T. (2011). Preliminary investigation on antimicrobial and proteolytic property of the epidermal mucus secretion of marine stingrays. Asian Pacific Journal of Tropical Biomedicine, 1(2), S239-S243.

Zaccone, G., Meseguer, J., García-Ayala, A., \& Kapoor, B. G. (2009). Fish defences volume I: Immunology. New Hampshire, USA: Science Publishers. 